\title{
THE DOMESTICATION OF MADNESS
}

\author{
by
}

\begin{abstract}
ANDREW SCULL*
WE use the term "domestic" and its cognates in at least two very different contexts. On the one hand, there is the contrast between the wild and the tame: the sense in which we refer to animals as "domesticated". And on the other hand, there is the reference to the private familial sphere, the environment of the home and one's intimate circle: domestic as contrasted with public life. In this paper I shall suggest that the changing social responses to madness from the end of the seventeenth to the early nineteenth centuries may be usefully looked at in terms of the metaphor of domestication, comprehending the transition from efforts to tame the wildly asocial to attempts to transform the company of the deranged into at least a facsimile of bourgeois family life.

During the early eighteenth century, most English medical writing on mental disorder was concerned, not with the Bedlam mad, ${ }^{1}$ but with the various manifestations of that Protean disorder, the grand "English malady", 2 to which ladies and gentlemen of quality (but especially ladies of quality) displayed such a striking susceptibility. To be sure, there were some discussions of the seriously mad - furious or moping - to which I shall return shortly; but the main focus of concern was clearly the various "nervous"' distempers - the spleen, hypochondria, the vapours, hysteria to which the physicians' fashionable clientele, blessed with excessively refined sensibilities and exquisitely civilized temperaments (not to mention money), were apt to fall victim. Such speculations (and I use the word advisedly) as Thomas Willis and his epigoni ventured on the subject of lunacy itself reflected an intellectual fascination with the difficult problem of providing a rational explanation of the origins and characteristics of madness, coupled with a marked distaste for any close or continuing contact with those suffering from the disorder: a combination not unknown among later generations of academic psychiatrists, and one which led John Monro to remark with some asperity that "the person who is most conversant with such cases, provided he has but common sense enough to avoid metaphysical subtleties, will be enabled by
\end{abstract}

\footnotetext{
*Andrew Scull, PhD, Department of Sociology, University of California, San Diego, California 92093. USA.

The research on which this paper is based was supported in part by a grant-in-aid from the Commonwealth Fund and by a fellowship from the John Simon Guggenheim Memorial Foundation, for which I am most grateful. Earlier versions were presented at the Wellcome Institute for the History of Medicine, London, and at Cambridge University. I should like to thank both audiences for their comments and suggestions.

' As Sir Richard Blackmore acknowledged, the subject of madness remained "a wild uncultivated region, an intellectual Africa, that abounds with an endless variety of monsters and irregular minds." Treatise of the spleen or vapours, London, 1724, p. 263.

${ }^{2}$ George Cheyne, The English malady: or, a treatise of nervous diseases of all kinds, London, Wisk, Ewing \& Smith, 1733.
} 


\section{A. Scull}

his extensive knowledge and experience to excell those who have not the same opportunities of receiving information." 3

And yet, while the utterances of a Willis, a Robinson, a Cullen on the aetiology and treatment of insanity reflect a remarkably restricted clinical acquaintance with the condition, they do mirror quite well a broader cultural consensus about the meaning of madness and the nature of the response one should make to it. Moreover, it seems to me that the fundamental thrust of what they have to say undermines or at the very least sharply limits the validity of Michael MacDonald's recent claim that the eighteenth century was marked by a shift away from more traditional stereotypes of mad behaviour, emphasizing irrational violence, furious raving, and incoherent bestiality. And it likewise undercuts Roy Porter's attempts to play down the distinctiveness of the moral treatment introduced at the end of the eighteenth century and to suggest the essential continuity between the reformers' programme and what had gone before. ${ }^{5}$

For whether one looks to theoretical medical texts, to works on the jurisprudence of insanity, to literary allusions, popular pictorial representations, or the practices of the despised madhouse keepers themselves, the dominant images are of whips and chains, depletion and degradation, the wreck of the intellect, and the loss of the madman's very human-ness; and madness's constant accompaniments are shit, straw, and stench. The traditional imagery to be found in Shakespeare, and in Elizabethan drama more generally, ${ }^{6}$

Love is merely a madness, and I tell you, deserves as well a dark house, and a whip, as madmen do: and the reason why they are not so punished and cured, is, that the lunacy is so ordinary, that the whippers are in love too.'

finds renewed expression in the more excremental outpourings of Jonathan Swift, who enjoins the madhouse keeper thus:

$$
\begin{aligned}
& \text { Tie them keeper in a tether } \\
& \text { Let them stare and stink together; } \\
& \text { Both are apt to be unruly, } \\
& \text { Lash them daily, lash them duly, } \\
& \text { Though 'tis hopeless to reclaim them, } \\
& \text { Scorpion Rods perhaps may tame them. }
\end{aligned}
$$

This sense of madness as a condition that required taming, as one might domesticate and thus render predictable the behaviour of a wild beast, runs through any number of eighteenth-century discussions of insanity. "Madmen", warned Thomas Willis, "are still strong and robust to a prodigy, so that they can break cords

${ }^{3}$ John Monro, Remarks on Dr. Batty's Treatise on madness, London, Clarke, 1758.

"See Michael MacDonald, "Insanity and the realities of history in early modern England", Psychol. Med., 1981, 11: 11-25.

' Roy Porter, 'The rage of party: a glorious revolution in English psychiatry?', Med. Hist., 1983, 27: 35-50.

'For example, Marston's What you will: "Shut the windows, darken the room, fetch whips; the fellow is mad, he raves, he raves - talks idly - lunatic." Or Shirley's Bird in a cage where the madhouse is referred to as "a house of correction to whip us into our senses." See generally, Edgar A. Peers, Elizabethan drama and its mad folk, Cambridge, Heffer, 1914.

'William Shakespeare, As you like it, Act III, Scene 2.

Jonathan Swift, The Legion Club, London, 1736, vol. 3, pp. 835-836. Note too that Tobias Smollett's Sir Launcelot Greaves concludes with both hero and heroine trapped in a private madhouse run by a $\mathrm{Mr}$ Shackle. 


\section{The domestication of madness}

and chains, break down doors or walls, one easily overthrows many endeavouring to hold him."' More extraordinarily yet, they "are almost never tired.... madmen, what ever they bear or suffer are not hurt; but they bear cold, heat, watching, fasting, strokes, and wounds, without any sensible hurt; to wit because the spirits being strong and fixed, are neither daunted nor fly away." 10 By mid-century, Richard Mead had extended this set of immunities a step further: madmen, it appeared, were likewise immune to the ravages of bodily disease, a formulation that was to be repeated almost by rote into the nineteenth century. ${ }^{11}$

But such striking immunity to the infirmities to which human flesh is heir were purchased at heavy price, for the descent into madness marked the divestment of "the rational Soul ... of all its noble and distinguishing Endowments." 12 If, as Foucault ${ }^{13}$ has argued, the madman's very animality protected him from all sickness and pathology, the bargain was nevertheless a poor one. The melancholy lunatic offered, said Nicholas Robinson, "the most gloomy Scene of Nature, that Mankind can possibly encounter, where nothing but Horror reigns; where the noble Endowments of the reasonable Soul are often disconcerted to a surprizing Degree, and this lordly creature then almost debas'd below the brutal Species of the animated Creation."14 Still more clearly was the maniac reduced in status, losing "that Power by which we are distinguished from the brutal Class of the animated Creation: 'til at last upon a Level, or rather beneath the Condition of a mere Brute."1s

"There is", said Mead, "no disease more to be dreaded than madness." 16 Such views were an eighteenth-century cliché, ${ }^{17}$ yet like many commonplaces, serve to reveal a great deal about contemporary beliefs. Dragged down to a state of brutish insensibility and incapacity, the lunatic occupied a wholly unenviable ontological status. Legally, as John Brydall pointed out in the first text on the jurisprudence of insanity, 18 he became virtually a nonentity, one whose "Promises and Contracts" were "void and of no force", and whose behaviour could never attain the dignity and status of human action. Such a creature, "deprived of his reason and understanding" could expect a miserable and humiliating career: "to attack his fellow creatures with fury

\footnotetext{
9 Thomas Willis, The practice of physick: two discourses concerning the soul of brutes, London: Dring, Harper, \& Leigh, 1684, p. 205. See also, William Salmon, A compleat system of physick, theoretical and practical, London, 1686, pp. 37, 56-61. Z. Mayne, Two dissertations concerning sense, and the imagination, London, 1728, p. 91.

10 Willis, op. cit., note 9 above, p. 205.

1 Richard Mead, Medical precepts and cautions, London, Brindley, 1751, p. 79; Thomas Arnold, Observations on the nature, kinds, causes, and prevention of insanity, 2nd ed; London, Phillips, 1806, vol. 2, pp. 155-156; Joseph Mason Cox, Practical observations on insanity, 2nd ed., London, Baldwin, 1806, pp. 4-5 ("No fact in medicine is more completely established.").

12 Nicholas Robinson, $A$ new system of the spleen, vapours, and hypochondriack melancholy, London, Bettesworth, Innys, \& Rivington, 1729, p. 241.

${ }^{13}$ Michel Foucault, Madness and civilization, New York, Mentor Books, 1965.

14 Robinson, op. cit., note 12 above, p. 243.

is Ibid., pp. 44, 50.

${ }^{16}$ Mead, op. cit., note 11 above, p. 74.

${ }^{17}$ See, for example, Robinson, op. cit., note 12 above, p. 50; Henry Mackenzie, The man of feeling, London, 1771, p. 73; Arnold, op. cit., note 11 above, vol. 2, p. 320; William Pargeter, Observations on maniacal disorders, Reading, [for the author], 1792, pp. 122, 139.

18 John Brydall, Non compos mentis; or, the law relating to natural fools, mad folks, and lunatick persons, London, Cleave, 1700.
} 


\section{A. Scull}

like a wild beast; to be tied down, and even beat, to prevent his doing mischief to himself or others: or, on the contrary, to be sad and dejected, to be daily terrified with vain imaginations; to fancy hobgoblins haunting him; and after a life spent in continual anxiety, to be persuaded that his death will be the commencement of eternal punishment." 19

Small wonder that the belief that madness was "a state, which is even more deplorable than death itself" 20 enjoyed widespread assent. After all, it brought "the mighty reasoners of the earth, below even the insects that crawl upon it ...". ${ }^{21}$ Neither, until the latter part of the century, was the gloom alleviated by any very confident claims from respectable quarters about the possibility of cure. Quacks like Thomas Fallowes, whose MD was awarded by himself, might advertise their "incomparable oleum cephalicum" as a sure cure for frenzy. ${ }^{22}$ Their orthodox competitors, however, were generally distinctly less sanguine. Willis, for example, held that "such being placed in Bedlam, or an hospital for Mad People, by the ordinary discipline of the place either at length returned to themselves or else they are kept from doing hurt to themselves or others." ${ }^{23}$ And Richard Mead lamented "this unhappy circumstance, that the disorder is very difficult to be cured." 24 Even John Monro, the physician to Bedlam and a man whose name was virtually synonymous with the mad-doctoring trade, thought "madness ... a distemper of such a nature that very little of real use can be said concerning it; the immediate causes will forever disappoint our search, and the cure of the disorder depends on management as much as medicine."2s

The madman remained, then, emblematic of chaos and terror, of the dark, bestial possibilities that lurked within the human frame, waiting only upon the loss of "that governing principle, reason" to emerge in their full awfulness. Once encounter a man "deprived of that noble endowment", warned William Pargeter, 26 "and see in how melancholy a posture he appears. He retains indeed the outward figure of the human species, but like the ruins of a once magnificent edifice, it only serves to remind us of his former dignity, and fill us with gloomy reflections with the loss of it. Within, all is confused and deranged, every look and expression testifies [to] internal anarchy and disorder." Notwithstanding the more hopeful portrayal of milder forms of mental disarray embodied in the early eighteenth-century textbooks on the spleen, the traditional view of Bedlam madness retained most of its old force and even content. Even towards the close of the century, mania wore its earlier garb, finding expression in "a violent and inordinate desire to do mischief; fury, vociferation, impetuosity of temper, and indomitable turbulence and vehemence; an angry and wild staring look in the eyes, actions rashly attempted, and as suddenly relinquished, obstinacy, perverseness, immodesty...", while its melancholic counterpart could be recognized

\footnotetext{
19 Mead, op. cit., note 11 above, pp. 74-75.

20 Pargeter, op. cit., note 17 above, p. 139.

${ }^{21}$ Samuel Richardson, The World, 7 June 1753.

22 Thomas Fallowes, The best method for the cure of lunaticks, London, [for the author], 1705.

${ }^{23}$ Willis, op. cit., note 9 above.

24 Mead, op. cit., note 11 above, p. 75.

${ }^{25}$ Monro, op. cit., note 3 above, advertisement. On this point at least, Monro agreed with the target of his polemic, William Battie. See Battie, A treatise on madness, London, Whiston \& White, 1758, p. 68.

${ }^{26}$ Pargeter, op. cit., note 17 above, pp. 2-3.
} 


\section{The domestication of madness}

"by sullenness, taciturnity, meditation, dreadful apprehensions, and despair."27

But still, under suitably controlled conditions, the varied beasts confined in "the wild abodes of secluded misery" 28 formed an entertaining display; an ever varied menagerie from which an audience made up of both provincial bumpkins and urban sophisticates could derive almost endless amusement. From Ned Ward's London spy to Mackenzie's Man of feeling, Bedlam offered, for a mere penny a time, the opportunity to view "the clamorous ravings, the furious gusts of outrageous action, the amazing exertion of muscular force, the proud and fanciful sallies of imagination" - if not perhaps "the excessive propensity to venereal intercourse" - that mad-doctors assured the public were the common currency of lunacy. ${ }^{29} \mathrm{And}$ by their thousands they came, as many as 100,000 in a good year, to what "was commonly regarded less as a hospital than as a kind of human zoo, with a fine, permanent exhibition of human curiosities." 30 All in all, an obvious setting for Hogarth to conclude his moral tract on the wages of sin (Figure 1), and an inevitable occasion for one of those floods of tears that Mackenzie's Man of feeling repeatedly inflicted on his readers: brought within the gates,

Their conductor led them first to the dismal mansions of those who are in the most horrid state of incurable madness. The clanking of chains, the wildness of their cries, and the imprecations which some of them uttered, formed a scene inexpressibly shocking. Harley and his companions, especially the female part of them, begged their guide to return: he seemed surprised at their uneasiness and was with difficulty prevailed on to leave that part of the house without showing them some others, who as he expressed it in the phrase of those that keep wild beasts for show, were much better worth seeing than any they had passed, being ten times more fierce and unmanageable. ${ }^{31}$

A generation or two later, as professional conceptions of insanity began to change quite sharply, John Haslam complained that "to constitute madness, the minds of ignorant people expect a display of continued violence, and they are not satisfied that a person can be pronounced in that state, without they see him exhibit the pranks of a baboon, or hear him roar and bellow like a beast." ${ }^{32}$ And his jibes were echoed by Thomas Bakewell, who described with some disdain the public reaction when a convalescent madman escaped from his Staffordshire madhouse: "The alarm this has excited has been very like what might be expected, were lion, or royal tiger, to escape from a caravan; and the censure upon my conduct has been such as would be cast upon a keeper of wild beasts, on such a terrific event." ${ }^{33}$ But their complaints have a somewhat disingenuous air, and not just because of medicine's long history of promoting

\footnotetext{
${ }^{27}$ William Rowley, A treatise on female, nervous, hysterical, hypochondriacal, bilious, convulsive diseases with thoughts on madness, suicide, etc., London, Nourse, 1788, p. 230.

${ }^{28}$ Andrew Harper, $A$ treatise on the real cause and cure of insanity, London, Stalker, 1789, p. iii.

29 Ibid., p. 26.

${ }^{30}$ Michael V. Deporte, Nightmares and hobbyhorses: Swift, Sterne, and Augustan ideas of madness, San Marino, California, Huntington Library, 1974, p. 3.

${ }^{31}$ Mackenzie, op. cit., note 17 above, pp. 73-74. Compare Ned Ward's description of his visit, some seventy years earlier: "Such rattling of chains, drumming of doors, ranting, holloaing, singing, and rattling, that I could think of nothing else but Don Quevado's vision where the damned broke loose and put Hell in an uproar." The London spy, 1698-1709, London, Folio Society, 1955, pp. 48-51.

32 John Haslam, Observations on madness and melancholy, London, Callow, 1809, pp. 77-78.

${ }^{33}$ Thomas Bakewell, A letter to the Chairman of the Select Committee on the State of Madhouses, to which is subjoined remarks on the nature, causes, and cure of mental derangement, Stafford, Chester, 1815 , p. 87.
} 
and reinforcing such stereotypes. For even as they sought to dismiss such images as the product of ignorance and superstition, as eminent a physician as Charles Bell was displaying graphic evidence of their survival in the highest professional circles in his Essays on the anatomy of expression in painting (Figure 2) ${ }^{34}$ To his sketches themselves, he appended a vivid description of his effort to render madness as it appeared in nature, as "ferocity amid the utter wreck of the intellect... a most unpleasant and distressing subject of contemplation." ${ }^{35}$ The essential requirement for the artist (to the neglect of which Bell attributed the romanticized images "we almost uniformly find given [to madmen] in painting") was "to learn the character of the human countenance when devoid of expression, and reduced to the state of brutality...". And for this task, nothing was more vital than to "have recourse to the lower animals; and as I have already hinted, study their expression, their timidity, their watchfulness, their state of excitement, and their ferociousness." ${ }^{36}$

Corresponding to these conceptions of the madman as beast were a set of therapeutic practices whose logic remained largely intact and unaltered over the course of more than a century. The madman's ferocity must be tamed, by a mixture of discipline and depletion designed to put down "the raging of the Spirits and the lifting up of the Soul." ${ }^{37}$ As Willis argued,

To correct or allay the furies and exorbitancies of the Animal Spirits ... requires threatenings, bonds, or
strokes as well as Physick. For the Madman being placed in House convenient for the business, must be
so handled both by the Physician, and also by the Servants that are prudent, that he may in some
manner be kept in, either by warnings, chidings, or punishments inflicted on him, to his duty, or his
behavior, or manners. And indeed for the curing of Mad people, there is nothing more effectual or
necessary than their reverence or standing in awe of such as they think their Tormentors. For by this
means, the Corporeal Soul being in some measure depressed and restrained, is compell'd to remit its
pride and fierceness; and so afterwards by degrees grows more mild, and returns in order; Wherefore,
Furious Madmen are sooner, and more certainly cured by punishments and hard usage, in a strait room,
than by Physick or Medicines.

Not that the lunatics were to escape the more conventional weapons of the medical practitioner, for, unless they were numbered among those not furious, but "more remissly Mad, [who] are healed often with flatteries, and with more gentle Physick,"39 "Bloodletting, Vomits, or very strong Purges, and boldly and rashly given, are most often convenient; [though for whom Willis does not say!] which indeed appears manifest, because Empericks only with this kind of Physick, together with a more severe government and discipline do not seldom most happily cure Mad folks." ${ }^{40} \mathrm{~A}$ misplaced caution and timidity were at all costs to be avoided in favour of a vigorous trial of the full rigors of the Galenic therapeutics; for "it is Cruelty in the highest Degree, not to be bold in the Administration of Medicine" in such cases. ${ }^{41}$ One must rather, said Robinson, have recourse to "a Course of Medicines of the most violent Operation... to bring down the Spirit of the Stubborn Persons... [and] to reduce

\footnotetext{
${ }^{34}$ Charles Bell, Essays on the anatomy of expression in painting, London, Longman, 1806.

${ }^{35}$ Ibid., pp. 155, 156.

36 Ibid., p. 155.

${ }^{37}$ Willis, op. cit., note 9 above, p. 206.

38 Ibid.

39 Ibid.

40 Ibid.

${ }^{4}$ Robinson, op. cit., note 12 above, p. 401.
} 


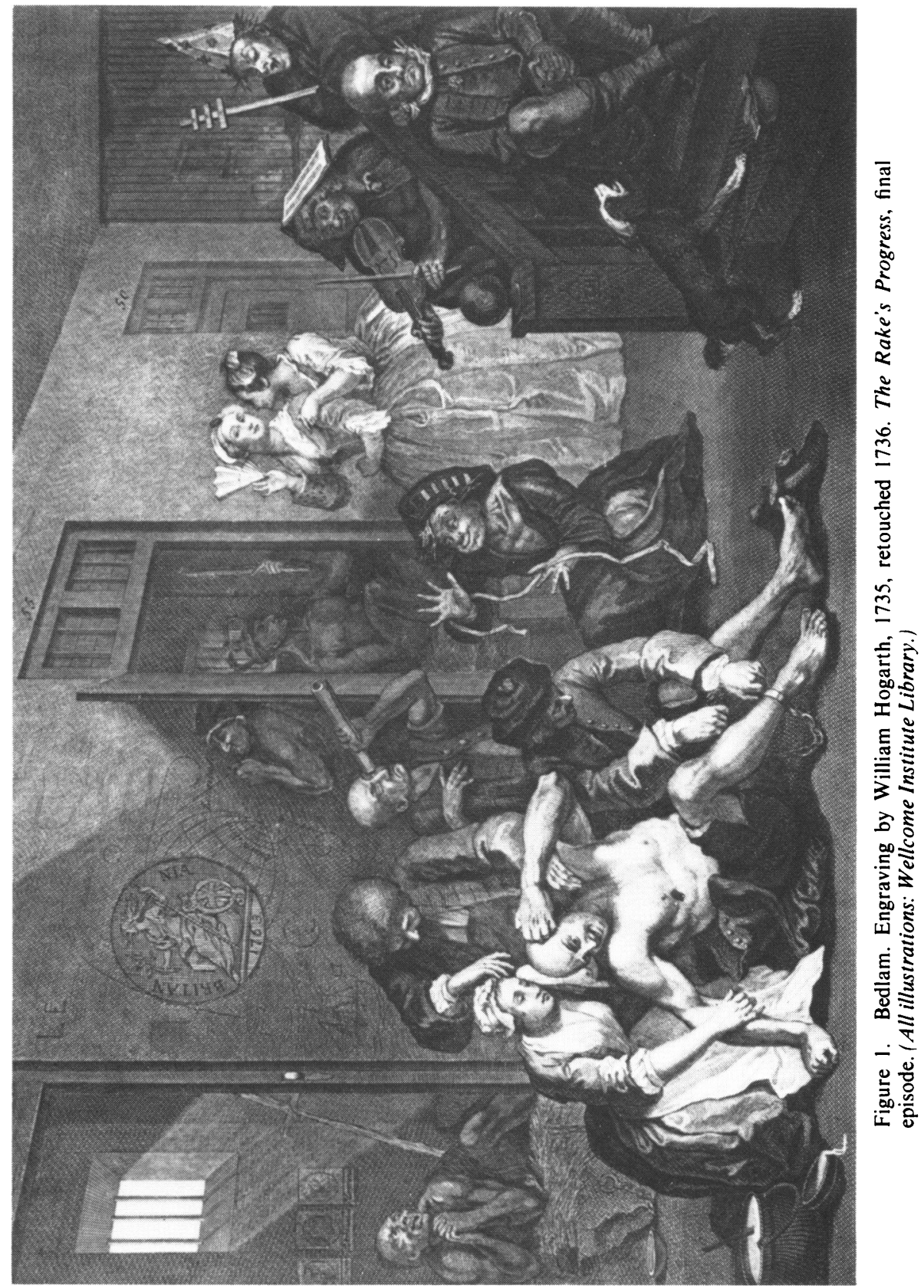



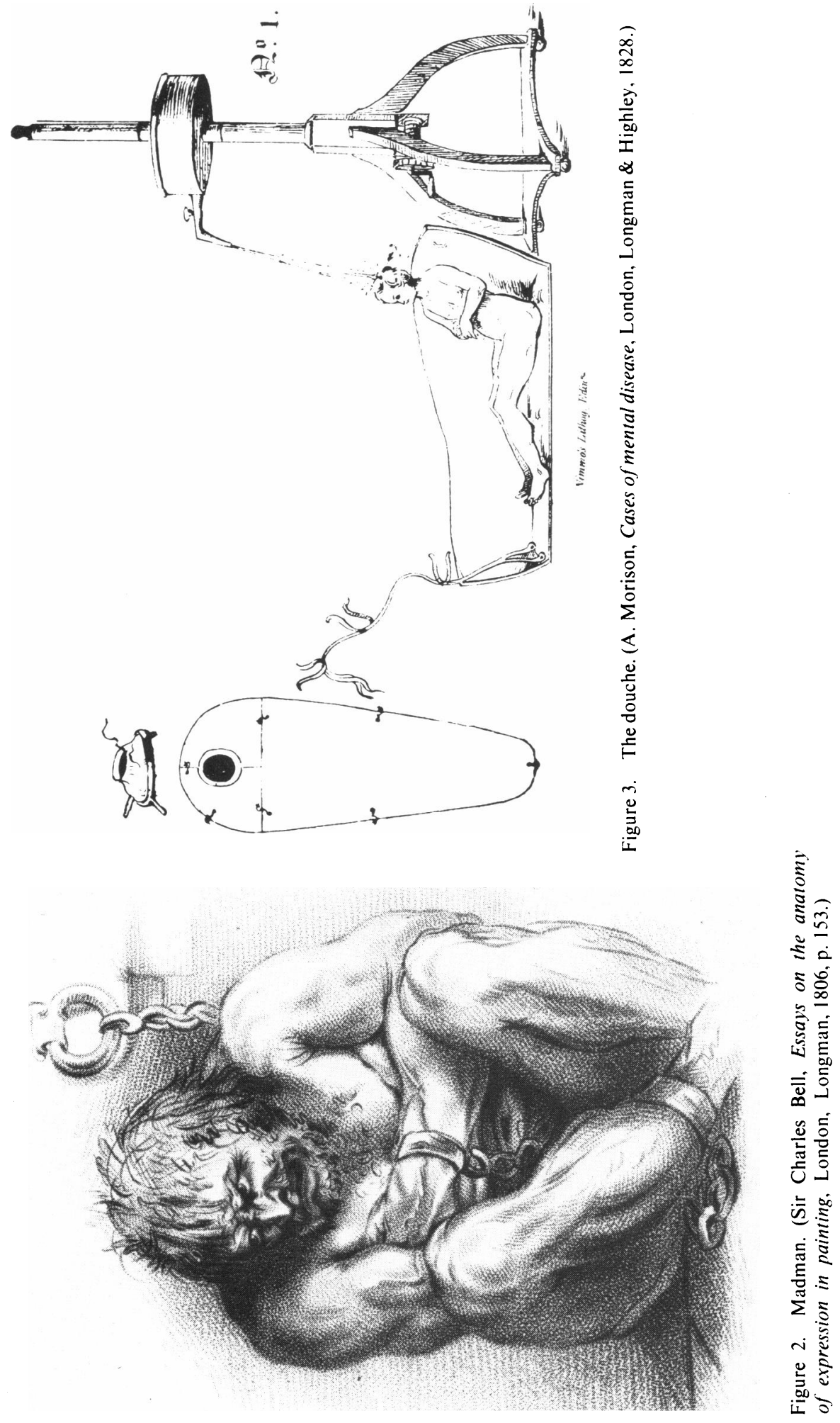

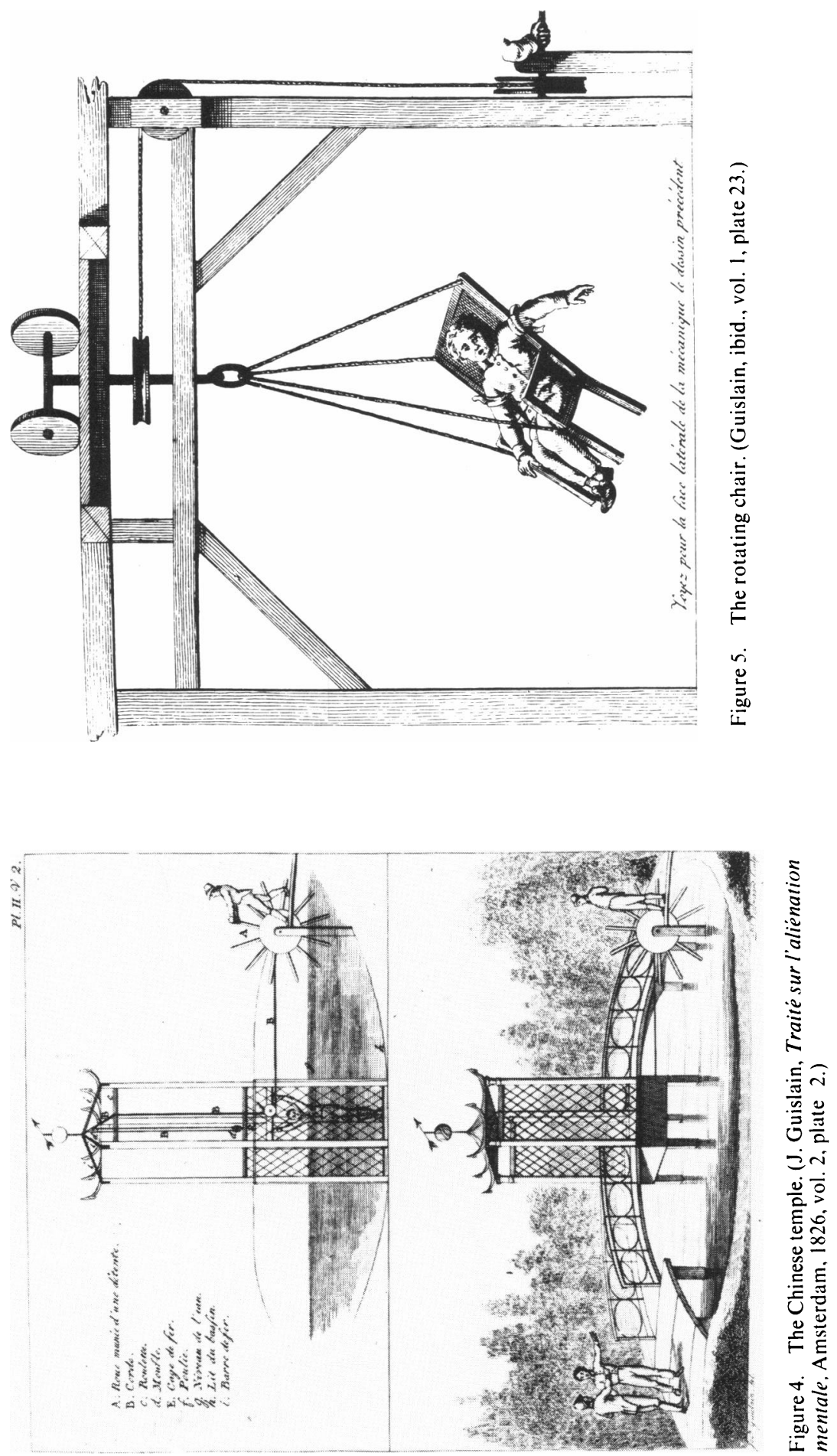


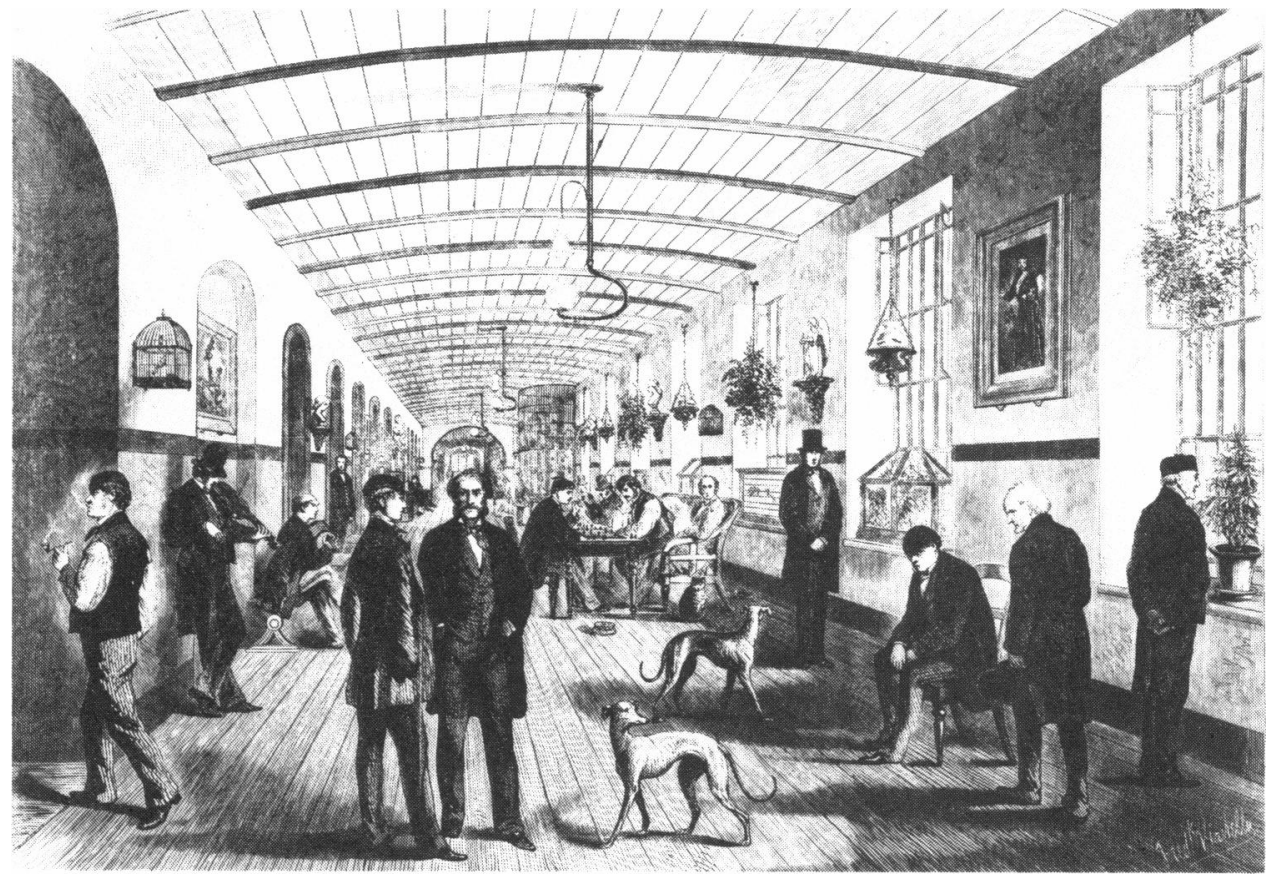

Figure 6. The men's gallery, Bedlam. (Illustrated London News, 1860, 36: 308.)

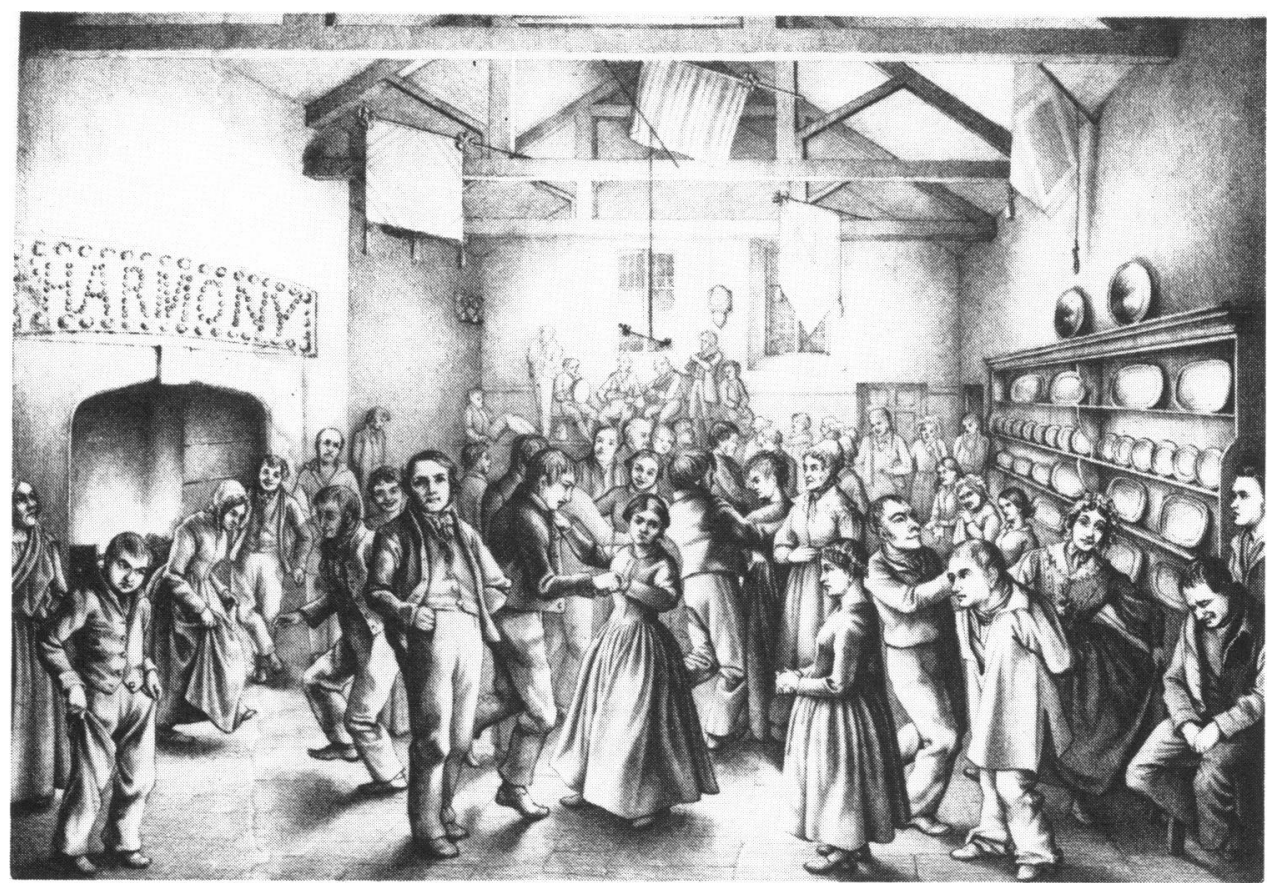

Figure 7. Lunatics' ball, Somerset County Asylum. Reproduction of lithograph by Katharine Drake, n.d. [early nineteenth century]. 


\section{The domestication of madness}

their artificial Strength by compulsive Methods." 42

Country clergymen, who dabbled in physik and found themselves consulted in the cure of the mad, were not always so convinced of the merits of coercing right thinking. Some indeed, like Southcomb, objected to "all those Means which tend to the giving of Pain and Uneasiness ... such as Blisters, Seatons, Cupping, Scarifying, and all other Punishments of the Like kind", urging that such "tormenting Means" often "rendered a very curable Disease, either incurable or [were] the Occasion of protracting the Cure longer than otherwise the Nature of the Case would have required." 43

For the most part, however, such pleas fell on deaf ears, at least as far as the medical profession was concerned. True, men like Richard Mead sometimes conceded that "it is not necessary to employ stripes or other rough treatment to bring [the outrageous] into order." " 4 But the objection was not to beating as such, only to its being superfluous, since "all maniacal people are fearful and cowardly." 4 "Diversions" would often suffice for those aflicted with "sadness and fear"; but "melancholy very frequently changes, sooner or later, into maniacal madness" and then one must once more have recourse to "chiding and threatening" and to the various weapons in the physician's therapeutic armamentarium..$^{46}$

Like his observation about the exemption of the mad from the ravages of other forms of disease, Mead's doctrine about the cowardliness of the insane was to prove widely influential, ${ }^{47}$ and came to underpin and give legitimacy to some of the most characteristic late-eighteenth-century responses to madness. As Sir George Onesiphorus Paul put it, more than half a century later, mad-doctors had determined that those on whom they practised "possessed a cunning and instinctive penetration, which makes them apprehend consequences from acts, and indeed to fear them; for they are universally cowardly. It is by keeping up this apprehension on their minds that they are so easily governed in numbers by the modern system of treating them." 48

"To superficial observers", remarked William Pargeter, "the conduct of maniacs ... appears extremely daring and courageous; but in reality they are exceedingly timorous and are found to be easily terrified." 49 (As we shall see, this did not restrain the medical profession from exercising considerable ingenuity to foment that terror.) To accomplish that management which both Battie ${ }^{50}$ and Monro $^{51}$ had urged as the key to the cure of the mad, the physician should ensure that his first visit was by surprise. But he must then "employ every moment of his time by mildness or menaces, as circumstances direct, to gain an ascendency over them, and to obtain their favour

42 Ibid., p. 400.

${ }^{43}$ Lewis Southcomb, Peace of mind and health of body united, London, Cowper, 1750, cited in Richard Hunter and Ida Macalpine, 300 Years of psychiatry, 1535 to 1860, Oxford University Press, 1963, p. 384.

${ }^{44}$ Mead, op. cit., note 11 above, p. 98.

${ }^{45}$ Ibid., p. 98.

${ }^{4}$ Ibid., pp. 98-99.

47 For example, David MacBride, A methodical introduction to the theory and practice of physick, London, Strahan, 1772, p. 592; William Falconer, $A$ dissertation on the influence of the passions upon disorders of the body, London, Dilly, 1788, p. 83; Cox, op. cit., note 11 above, p. 34.

${ }^{48}$ Sir George Onesiphorus Paul, in Report of the Select Committee on Criminal and Pauper Lunatics, London, 1807, p. 16.

49 Pargeter, op. cit., note 17 above, p. 61.

${ }^{30}$ Battie, op. cit., note 25 above.

${ }^{31}$ Monro, op. cit., note 3 above. 


\section{A. Scull}

and prepossession." 32 Much depended here upon the mad-doctor's skill at managing his presentation of self, since "he may be obliged at one moment, according to the exigency of the case, to be placid and accommodating in his manners, and the next, angry and absolute." ${ }^{33}$ Consequently, as Joseph Mason Cox noted,

There are very few, whom nature has been so kind as to qualify for the practice; every man is not furnished with sufficient nerve, with the requisite features for the varied expression of countenance which may be necessary, with the degree of muscular powers, or stature, etc. [But all, at least, could recognize that] the grand object in their moral management, is to make ourselves both feared and loved, nothing can so successfully tend to affect this as a system of kindness and mildness, address and firmness, the judicious allowance of indulgences, and the employment of irresistible control and coercion. ${ }^{34}$

Sometimes the coercion and control were quite straightforward. Bakewell, for example, relates an instance from his practice where "a maniac confined in a room over my own ... bellowed like a wild beast, and shook his chain almost constantly for several days and nights. ... I therefore got up, took a hand whip, and gave him a few smart stripes upon the shoulder ... he disturbed me no more." ${ }^{5}$ Such techniques were generally expected to be efficacious since, as Falconer put it, "Those who attend them ... mostly find, that although generally irrational, they retain a great consideration for personal safety, and that threats will often compel them to speak and act rationally." 36

But direct physical threats were not always necessary. "It is of great use in practice", said MacBride, "to bear in mind, that all mad people ... can be awed even by the menacing look of a very expressive countenance; and when those who have charge of them once impress them with the notion of fear, they easily submit to anything that is required." 37 Indeed, "the eye" was perhaps the most dramatic technique that the late-eighteenth-century mad-doctor claimed to have at his disposal, and was used most famously by Francis Willis in his treatment of George III. ${ }^{.8}$ Benjamin Rush

32 Pargeter, op. cit., note 17 above, p. 49.

33 Ibid., p. 50.

s4 Joseph Mason Cox, Practical observations on insanity, 3rd ed., London, Baldwin and Underwood, 1813, p. 84.

ss Thomas Bakewell, The domestic guide in cases of insanity, Stafford, 1805, cited in Hunter and Macalpine, op. cit., note 43 above, p. 705.

36 Falconer, op. cit., note 47 above, p. 83

37 MacBride, op. cit., note 47 above, p. 592.

s8 Following George III's recovery from his attack of "mania" in 1788, a parliamentary committee, among whose members were Burke and Sheridan, inquired into the king's treatment. During the course of these inquiries, it was revealed that Willis had allowed the king to shave himself with a cut-throat razor. The other royal physicians criticized Willis about this. "Burke also was very severe on this point, and authoritatively and loudly demanded to know, "If the Royal patient had become outrageous at the moment, what power the Doctor possessed of instantaneously terrifying him into obedience?'

'Place the candles between us, Mr Burke,' replied the Doctor, in an equally authoritative tone - 'and I'll give you an answer. There Sir! by the EYE! I should have looked at him thus, Sir - thus!'

Burke instantaneously averted his head, and, making no reply, evidently acknowledged this basiliskan authority." The life and times of F. Reynolds, written by himself, London, 1826, vol. 2, pp. 23-24.

If necessary, Willis used more than just "the eye" to secure the measure of obedience he saw as indispensable. His reputation for using force and fear to cow his patients was such that when he was called in to treat George III, the queen was extremely reluctant to allow him to proceed: "It was known to her, that the first principle of Dr W's practice is, to make himself formidable - to inspire awe. In these terrible maladies, those who superintend the unhappy patients must so subjugate their will, that no idea of resistance to their commands can have place in their minds. It was but too obvious, that the long and habitual exercise of high command must increase the difficulty of accomplishing this, in the present instance; - and an apprehension 


\section{The domestication of madness}

even went so far as to claim that, "There are keys in the eye, if I may be allowed the expression" which allowed the skilled practitioner to vary "its aspect from the highest degree of sternness, down to the mildest degree of benignity" and thus to secure minute changes in the patient's behaviour. ${ }^{39}$ And the growing clinical literature of the period is replete with case histories like this one, offered by William Pargeter:60

The maniac was locked in a room, raving and exceeding turbulent. I took two men with me, and learning he had no offensive weapons, I planted them at the door with directions to be silent and keep out of sight, unless I should want their assistance. I then suddenly unlocked the door - rushed into the room and caught his eye in an instant. The business was then done - he became peaceable in a moment trembled with fear, and was as governable as it was possible for a furious madman to be.61

One must realize, however, that the excitement of fear and the infliction of physical suffering were forms of treatment resting upon a more elaborate theoretical basis than I have yet demonstrated. Madness was essentially defined, indeed constituted, by the preternatural force with which certain irrational ideas dominated the mind, heedless of the ordinary corrective processes provided by experience and persuasion. The madman's loss of contact with our consensually defined reality, his spurning of common sense, reflected how deeply the chains of false impressions and associations were engraved upon his system. There were differences in degree between mania and melancholia: "The distinguishing character of [the latter] is an attachment of the mind to one object, concerning which the reason is defective, whilst in general it is perfect in what respects of the subjects ...," whereas mania entailed "an irrationality on all subjects." 62 And these differences argued for the use of a greater caution in handling the melancholic. But in both forms of the disorder, the thought processes were trapped in erroneous pathways - a language which reified and referred them to an underlying disorder of a (somewhat variously conceived) physical substratum of thought, from whose grip they must somehow be shaken loose.

The very tenacity with which maniacs adhered to their false and mistaken perceptions testified to the weight and strength with which these were impressed upon the brain, and by implication required and justified the extremity of the measures adopted to jolt the system back into sanity. Given that "the mind when waking is always active and employed", it followed that "we have no method of banishing one set or train of ideas, but by substituting another in its place." 63 And in view of the entrenched posi-

of the necessity of peculiar rigour gave all possible aggravation to the queen's distress." But Willis refused to modify his practice, insisting that "he might be permitted to act without control. He said that there was but one method, in that complaint, by which the lowest and the highest person could be treated with effect; and that his reputation was too much concerned in the event, for him to attempt anything, if he might not be invested with unlimited powers." The queen capitulated. [Anonymous], Some particulars of the royal indisposition of 1788 to 1789, and of its effects upon illustrious personages and opposite parties interested by it, London, [printed for the editor by R. Taylor], 1804, pp. 31-33.

s9 Benjamin Rush, Medical inquiries and observations upon the diseases of the mind, Philadelphia, 1830, pp. 173-174.

0 Pargeter, op. cit., note 17 above, pp. 50-51, also pp. 58-59.

1 John Haslam (op, cit., note 32 above, p. 276), incidentally, was as scathing about such stories as about most other claims put forward by his fellow mad-doctors: "It has, on some occasions, occurred to me to meet with gentlemen who have imagined themselves eminently gifted with this awful imposition of the eye, but ... I have never been able to persuade them to practice this rare talent tête à tête with a furious lunatic."

62 Falconer, op. cit., note 47 above, pp. 77, 82.

${ }^{63}$ Ibid., p. 4. 


\section{A. Scull}

tion occupied by the opposing ideas, one could only hope "to eradicate the false impressions by others still more violent." 64 Thus were intimidation and forceful persuasion embodied in a variety of physical treatments, which simultaneously brought moral and physiological pressures to bear on the patient, and aimed to break "the chain of ideas which possessed the mind," even - what a splendid choice of words - if possible to "exterminate" them. ${ }^{65}$

Sometimes not just the insane ideas were exterminated. Throughout the century, classical sources were drawn upon for inspiration, as the search went on for a suitable means of inducing the appropriate degree of terror. But there was a veritable paroxysm of inventiveness at the turn of the century, as the techniques of the Industrial Revolution were adapted to the task at hand. Elaborate systems of plumbing were developed to deliver forcible streams of cold water to the head of a suitably restrained maniac (Figure 3). Boerhaave's suggestion that near-drowning be employed for its salutary effects gave birth to a variety of ingenious devices designed to produce this effect: hidden trapdoors in corridors designed to plunge the unsuspecting lunatic into a "bath of surprise" as well as coffins with holes drilled in their lids, into which the patient could be fastened before being lowered under water. As Guislain put it, the two critical aims to be realized, in constructing such an apparatus, were to obtain complete mastery of the madman, and to avoid drowning him (in that order). Francis Willis's attempt to reconcile these imperatives struck him as imperfect, prompting him to offer an improved version of his own (Figure 4). As he describes it,

It consists of a little Chinese temple, the interior of which comprises a moveable iron cage, of lightweight construction, which plunges down into the water descending in rails, of its own weight, by means of pulleys and ropes. To expose the madman to the action of this device, he is led into the interior of this cage: one servant shuts the door from the outside while the other releases a brake which, by this maneuver, causes the patient to sink down, shut up in the cage, under the water. Having produced the desired effect, one raises the machine again, as can be seen from the drawing attached.

Generally, he continued gravely, the treatment could only be applied once to each lunatic, and, he warned, "Toute fois ce moyen sera plus ou moins dangereux." 66

Some sought to improve instruments of restraint to ensure "all the tenderness and indulgence compatible with steady and effectual government." 67 Benjamin Rush, for example, who trained under Cullen at Edinburgh (like so many mad-doctors of the late eighteenth century), designed an elaborate "tranquillizing chair", whose good effects in coercing a measure of good behaviour from his patients he was not slow to advertise. ${ }^{68}$ There was even a debate of sorts between those who preferred "the strait

64 Ibid., p. 82. Compare also Cox, op. cit., note 11 above, p. 45.

6s Alexandre Brière de Boismont, On hallucinations: a history and explanation, London, Renshaw, 1859.

6o J. Guislain, Traité sur l'aliénation mentale et sur les hospices des aliénés, Amsterdam, Hey, 1826, pp. 43-44.

67 Thomas Percival, Medical ethics, Manchester, Johnson \& Bickerstaff, 1803.

63 As he wrote to his son, James, on 8 June 1810: "I have contrived a chair and introduced it to our [Pennsylvania] Hospital to assist in curing madness. It binds and confines every part of the body. By keeping the trunk erect, it lessens the impetus of blood toward the brain. By preventing the muscles from acting, it reduces the force and frequency of the pulse, and by the position of the head and feet favors the easy application of cold water or ice to the former and warm water to the latter. Its effects have been truly delightful to me. It acts as a sedative to the tongue and temper as well as to the blood vessels. In 24,12 , six, and in some cases in four hours, the most refractory patients have been composed. I have called it a Tranquilizer." Rush to James Rush in L. H. Butterfield (editor), The letters of Benjamin Rush, Princeton, N.J., Princeton University Press, 1951, vol. 2, p. 1052. 


\section{The domestication of madness}

waistcoat, with other improvements in modern practice", on the grounds that they "preclude[d] the necessity of coercion by corporal punishment" 69 and those who preferred "metallic manacles on the wrist; the skin being less liable to be injured by the friction of polished metal than by that of linen or cotton." "10 (Paul Slade Knight endorsed the latter opinion, though he cautioned that "the clinking of the chains should be, by all means, prevented, for I have known it impress lunatics with the most gloomy apprehensions." 1

Perhaps the most famous of all at the time was Joseph Mason Cox's swinging device (Figure 5). The idea for it had come from Erasmus Darwin, who in turn had derived it from classical suggestions about the value of swinging as a therapy. ${ }^{12}$ But Cox was the first to develop a working model, and his book describing its construction and use $^{73}$ rapidly went through three English editions, as well as appearing in an American and a German edition; his device was recommended by Knight and Hallaran as "a machine that should be easily accessible in every asylum for Lunatics." 74

Like Rush's tranquillizer, the swing acted simultaneously on both physiological and mental levels, allowing the physician to exploit "the sympathy or reciprocity of action that subsists between mind and body." In the application of this sovereign remedy, each became "in its turn the agent, and the subject acted on, as when fear, terror, anger, and other passions, excited by the action of the swing, produce various alterations in the body, and where the revolving motion, occasioning fatigue, exhaustion, pallor, horripilatio, vertigo, etc. effect [sic] new associations and trains of thought." 75 The "mechanical apparatus" provided the operator with the inestimable advantage of being able to regulate the whole process with extraordinary precision. One could, for example, vary its effects on the stomach so as to produce "either temporary or continued nausea, partial or full vomiting", and if necessary could secure "the most violent convulsions ... the agitation and convulsion of every part of the animal frame." 76 Even the most obstinate cases could not long resist its powers: if necessary it could be "employed in the dark, where, from unusual noises, smells, or other powerful agents, acting forcibly on the senses, its efficacy might be amazingly increased." And by "increasing the velocity of the swing, the motion be[ing] suddenly reversed every six or eight minutes, pausing occasionally, and stopping its

\footnotetext{
69 Percival, op. cit., note 67 above.

${ }^{70}$ Charles Dickens and W. H. Wills, 'A curious dance around a curious tree', Household Words, 17 January 1852.

"Paul Slade Knight, Observations on the causes, symptoms, and treatment of derangement of the mind, London, Longman, 1827, p. 116.

72 Erasmus Darwin, Zoonomia; or, the laws of organic life, 2 vols., London: Johnson, 1796; Darwin's source was probably H. Mercurialis, De arte gymnastica, Amsterdam, 1672. For this reference I am indebted to Dr Vivian Nutton.

${ }^{73}$ Cox, op. cit., note 11 above.

${ }^{74}$ Knight, op. cit., note 71 above, p. 63; William Saunders Hallaran, An inquiry into the causes producing the extraordinary addition to the number of insane, Cork, Ireland, Edwards \& Savage, 1810; Idem. Practical observations on the causes and cure of insanity, Cork, Ireland, Hodges \& M'Arthur, 1818.

is Cox, op. cit., note 11 above, pp. 168-169.

76 Ibid., pp. 143-144.

77 Ibid., p. 140.
} 


\section{A. Scull}

circulation suddenly: the consequence is, an instant discharge of the contents of the stomach, bowels, and bladder, in quick succession."7s

The consequent "very violent shock both to mind and body" exhibited a wholly salutary "tendency to excite fear or terror." $" 9$ Hallaran subsequently carried the whole process to a higher pitch of perfection, designing a seat which "supports the cervical column better, and guards against the possibility of the head in the vertiginous state from hanging over the side [sic]"; $; 0$ and placed it in an improved version of the apparatus that allowed four patients to be treated simultaneously at speeds of up to 100 revolutions a minute. Elaborate case histories documented its immense usefulness as an agent of moral repression, reducing the most violent and perverse to a meek obedience.

Yet notwithstanding all such encomiums, the half-life of the gyrating chair proved exceedingly brief. By 1828 , George Man Burrows was complaining that, despite his personal conviction of the swing's therapeutic value, public sentiment was such that he dared not make use of it, fearing lest, given "the morbid sensitivity of modern pseudophilanthropy", any accident attending its use would leave him "universally decried, his reputation blasted, and his family ruined." 81 The authorities in Berlin and Milan had already banned its use, and it rapidly disappeared from English asylums as well.

Its demise formed part of a wider rejection of traditional modes of managing the mad (as well as the rationales underlying them) that spread ever more widely in the first half of the nineteenth century. The mixture of incomprehension and moral outrage with which formerly respectable therapeutic techniques came to be viewed was captured most vividly by Charles Dickens, who spoke scathingly of the mad-doctors' "wildly extravagant, . . . monstrously cruel monomania", their bizarre insistence "that the most violent and certain means of driving a man mad, were the only hopeful means of restoring him to reason." "'2 "What sane person", he asked, "seeing, on his entrance into any place, gyves and manacles (however highly polished) yawning for his ankles and wrists; swings dangling in the air, to spin him around like an impaled cockchafer; gags and strait waistcoats ready at a moment's notice to muzzle and bind him; would be likely to retain the perfect command of his senses?"'s

It was not just the outwardly visible apparatus of physical restraint and coercion that began to lose its legitimacy (a process that culminated in Gardiner Hill and Conolly's triumphant claims to have secured the total abolition of mechanical restraint). ${ }^{84}$ Rather, the very attempt to tame madness was increasingly viewed as

\footnotetext{
"George Man Burrows, Commentaries on the causes, forms, symptoms, and treatment, moral and medical, of insanity, London, Underwood, 1828, p. 601.

7 Cox, op. cit., note 11 above, p. 170.

20 Burrows, op. cit., note 78 above, p. 601.

21 Ibid., p. 606.

22 Dickens and Wills, op. cit., note 70 above, p. 385.

'3 Ibid. In similar language, Samuel Tuke had earlier condemned "those swingings, whirlings, suspensions, half-drowning and other violent expedients by which some physicians have sought to frighten the unhappy subject into reason, or at least into subjection." Introductory observations to M. Jacobi, On the construction and management of hospitals for the insane, London, Churchill, 1841, p. 54.

* Robert Gardiner Hill, A lecture on the management of lunatic asylums and the treatment of the insane, London, Simpkin, Marshall, 1839; John Conolly, The treatment of the insane without mechanical restraints, London, Smith, Elder, 1856.
} 


\section{The domestication of madness}

seriously misguided. Samuel Tuke commented that by means of terror, lunatics

may be made to obey their keepers with the greatest promptitude, to rise, to sit, to stand, to walk, or run at their pleasure; though only expressed by a look. Such an obedience, and even the appearance of affection, we not infrequently see in the poor animals who are exhibited to gratify our curiosity in natural history; but, who can avoid reflecting, in observing such spectacles, that the readiness with which the savage tiger obeys his master, is the result of treatment at which humanity would shudder. ${ }^{\text {ss }}$

Within the new orthodoxy, attempts to compel patients to think and act reasonably were themselves stigmatized as unreasonable: ${ }^{26}$ "intimidation and coercion may make or modify the symptoms of insanity, but can seldom produce permanently good effects."

The nineteenth-century domestication of madness proceeded in a wholly different direction, reducing rage and despair to at least a simulacrum of moderation, order, and lawfulness, ${ }^{88}$ and transforming the imagery of confinement from the "pigstyes"so in which, as Wynter put it, the mad had been "hung from their fetters and chains on the wall like vermin chained to a barn door", 90 to the peaceful Potemkin villages that were Conolly's and W. A. F. Browne's vision of what asylums "are and ought to be." 11 Here,

calmness will come; hope will revive; satisfaction will prevail . . a almost all disposition to meditate mischievous or fatal revenge, or self-destruction, will disappear . . . cleanliness and decency will be maintained or restored; and despair itself will sometimes be found to give place to cheerfulness or secure tranquility. [This is the place] where humanity, if anywhere on earth, shall reign supreme.92

In the new iconography, madness was reined in amidst the comforts of domesticity by the invisible yet infinitely potent fetters of the sufferer's own "desire for esteem", complemented by the benevolent authoritarianism of the asylum superintendent and the healthful influences of the new moral architecture.

A quasi-mythical scene recurs repeatedly: a maniac is brought to the asylum gates, frenzied, furious, exhibiting all the signs of dangerous and violent alienation, and in consequence laden with irons and chains. The alienist appears, and in the face of assurances from the man's captors that release will mean certain death for the bystanders, calmly orders that the bonds be discarded and leads the lamb-like madman into dinner. "I treat them", said Thomas Bakewell, "exactly as I should do if they were not afflicted with that disease, and, in return, they almost uniformly behave as if nothing was the matter with them."93

"Language and actions" were once more to "become subordinate to a wellregulated will"'94 by inducing the madman to control himself. A man's madness was not to be reasoned with or refuted - a useless, even dangerous endeavour. Its content

8s Samuel Tuke, Description of the Retreat, York, Alexander, 1813, pp. 147-148.

26 John Conolly, in Hanwell Lunatic Asylum Annual Report 1840, pp. 55-56, 70.

'7 T. Harrington Tuke, 'On warm and cold baths in the treatment of insanity', J. ment. Sci., 1858, 5: 102.

"Jacobi, op. cit., note 83 above.

- Report of the Select Committee on Madhouses, 1815, evidence of Henry Alexander, p. 21.

${ }^{9}$ Andrew Wynter, The borderlands of insanity, London, Hardwicke, 1875, p. 85.

$91 \mathrm{~W}$. A. F. Browne, What asylums were, are and ought to be, Edinburgh, Black, 1837.

92 John Conolly, On the construction and government of lunatic asylums, London, Churchill, 1847, p. 143.

${ }^{93}$ Bakewell, op. cit., note 55 above, p. 57; see also T. O. Prichard in The Northampton Lunatic Asylum Annual Report 1840; and Tuke, op. cit., note 85 above.

94 Conolly, op. cit., note 86 above, pp. 70-71. 


\section{A. Scull}

was ignored; its existence the lunatic had to be taught to suppress.95

Central to the new approach, as I have argued at more length elsewhere, was the internalization of control,96 a goal which necessarily entailed a move away from regime of undifferentiated restraint and fear. It required instead the recognition of the lunatic's sensibility, and the acknowledgement (in a highly limited and circumscribed sense) of his status as a moral subject. Contrary to previous practice, the madman must not be addressed "in a childish, or . . . domineering manner", ${ }^{97}$ for this threatened to subvert the effort to rouse his "moral feelings", and to use these as "a sort of moral discipline". 98 "Certainly authority and order must be maintained, but these are better maintained by kindness, condescension, and indulgent attention, than by any severities whatever. Lunatics are not devoid of understanding, nor should they be treated as if they were; on the contrary, they should be treated as rational beings." 99

They were also to be treated in an environment that was self-consciously domestic in a more conventional sense. There was a tireless insistence that the inmates of an asylum were a family, and that the discipline to which they were subject "naturally arises from the necessary regulations of the family." 100 And this fictional domesticity was tenaciously maintained (linguistically at least) even after the thirty patients of Tuke's retreat had become the 1000 or more that swarmed into the burgeoning county asylum: Conolly moving among the hordes at Hanwell is described as "like a father among his children, speaking a word of comfort to one, cheering another, and exercising a kindly and humane influence over all." 101

\footnotetext{
9s In Bakewell's words (op. cit., note 55 above, p. 38), "The effects of strong mental feelings are not to be counteracted by the conceptions of thought that arise from argument ... in our endeavours to counteract the erroneous thoughts of lunatics we are not to expect anything but mischief, from the powers of argument, upon their particular hallucinations; all we can do is to promote a new train of mental images." Compare also Samuel Tuke's comment in Description of the Retreat (op. cit., note 85 above), "No advantage has been found to arise from reasoning with them on their particular hallucinations ... in regard to melancholics, conversation on the subject of their despondency is found to be highly injudicious. The very opposite method is pursued. Every means is taken to seduce the mind from its favorite but unhappy musings, by bodily exercise, walks, conversation, reading, and other innocent recreations." In some respects, then, the proponents of moral treatment agreed with those wedded to more traditional approaches. For as we have seen, eighteenth-century physicians also thought that the successful treatment of madness was dependent upon the therapist's possession of the capacity "of the artful association of ideas and of the art of breaking false or unnatural associations, or inducing counter-associations." John Gregory, A comparative view of the state and faculties of man with those of the animal world. London, Dodsley, 1765, pp. 186-188. What changed were notions about the way these goals were to be realized. (In view of the often made connexion between the adoption of Lockean views on the nature and sources of insanity and the reliance upon "mild" forms of treatment, it is perhaps worth noting that proponents of the older heroic approach could with equal justice have defended their practices on Lockean grounds. For example, Locke's emphasis on the direct relationship between the strength of a particular sensation and the vividness of any given idea could be readily coupled with the notion that the cure of madness required the supersession of defective learned patterns of thought, to legitimize the most extreme versions of therapeutic terror. The very existence of these diametrically opposed "implications" of Locke's ideas surely points up the limitations of any purely internalist account of changing responses to madness.)

96 Andrew Scull, Museums of madness, London, Allen Lane, 1979; idem, 'Moral treatment reconsidered: some sociological comments on an episode in the history of British psychiatry', Psychol. Med., 1979, 9.

${ }^{97}$ Tuke, op. cit., note 85 above.

9 Bakewell, op. cit., note 55 above, p. 59.

9 Ibid., pp. 55-56. See also Benjamin Faulkner, Observations on the general and improper treatment of insanity, London, Reynell, 1789, passim.

100 Tuke, op. cit., note 85 above.

101 Wynter, op. cit., note 90 above, p. 108, quoting Forbes Winslow.
} 


\section{The domestication of madness}

As this suggests, the asylum regime in practice was no more than a grotesque caricature of the domestic circle: and the insistence on the domestic imagery is the more ironic inasmuch as it coincides with the decisive removal of madness from family life. ${ }^{102}$ But certainly insanity now assumed a more placid, less threatening garb, so much so that there were suggestions that "insanity has undergone a change, and that, whilst there is an increase in the number of cases of the disease, there is happily a marked diminution of its most formidable modifications, furious mania." 103 Those running the asylums naturally preferred to see the change as an illustration of "the mildness and tractability of its forms under a humane and rational direction", ${ }^{104}$ and to urge, with Conolly, that "mania, not exasperated by severity, and melancholia, not deepened by the want of all ordinary consolations, lose the exaggerated character in which they were formerly beheld." 105

If cures swiftly proved beyond its reach in all but a small minority of cases, the asylum regime at least provided the public with symbolic demonstrations that the disturbing and dangerous manifestations of madness were firmly under control; that the disorderly could be rendered tranquil and tractable. Tuke's famous image of the inmates of the Retreat calmly sipping tea and exchanging social pleasantries found its echo in the county asylum reports of the mid-century. At Hanwell on the occasion of the Matron's birthday, 200 patients

assembled in Ward Number 10, the decoration of which had previously afforded amusing occupation to some of them. They drank tea in the Airing Court, and were afterwards allowed to amuse themselves by dancing in the galleries, a piano having been removed thither for the purpose. It is impossible to image a more happy party. The utmost liveliness was combined with perfect good behaviour. . . . Soon after eight o'clock they joined in singing the Evening Hymn, and returned, with perfect order, and many grateful expressions, to their respective wards. ${ }^{106}$

The mad could even be granted the consolation and the "indulgence of going to Chapel". Once again, they could be relied upon to preserve a perfect decorum. Indeed,

so accustomed are the Patients to preserve their composure during the hour of service, that if, as sometimes happens, an Epileptic patient utters a loud scream, falls into a fit, and requires to be taken out by the keepers or nurses; very few of the Patients quit their seats; and those in the immediate neighbourhood of the person affected usually render what assistance they can, and then quietly resume their places. ${ }^{107}$

Soon the public no longer had to take such portraits on trust. As they had been allowed in to view the menagerie at Bedlam a century earlier, so they were now invited (albeit under more restricted and controlled conditions) to move across the boundary wall of the asylum that divided the mad from the sane (Figure 6). And once inside, the question that most frequently occurred was, where were all the mad people? ${ }^{108}$ In

${ }^{102}$ Scull, Museums, op. cit., note 96 above.

${ }^{103}$ Cited in Northampton Lunatic Asylum Annual Report 1840.

104 T. O. Prichard, in ibid.

105 John Conolly, cited in Sir James Clarke, A memoir of John Conolly, London, 1869, p. 28.

${ }^{106}$ Conolly, op. cit., note 86 above, p. 79.

107 Ibid., pp. 86-87.

108 In Harrington Tuke's words, "The very type of the malady seemed to be changed; fearful, raving, desperate struggling, and maniacal excitement, heretofore the ordinary symptoms of mental disease, were now seldom seen ... the aspect and demeanor of the patients became so altered, that a foreign physician visiting the asylum, after seeing all its inmates, gravely inquired "where all the real lunatics were confined?" Harrington Tuke, 'Address of the President to the British Medical Association, Section of Psychology', Br. med. J., October 1873, reprinted as a separate pamphlet, pp. 4-5. See also for example, Atheneum, 1842, 


\section{A. Scull}

Elaine Showalter's words, ${ }^{109}$ "madness was no longer a gross and unmistakable inversion of appropriate conduct, but a collection of disquieting gestures and postures." Even the forces of sexuality had been successfully brought under control. ${ }^{110}$ MidVictorian asylums usually enforced a monastic segregation of the sexes. (The Lunacy Commissioners even complained when the "deadhouse" at the Cambridge County Asylum was shared by corpses of the opposite sex. ${ }^{111}$ ) But one exception to this policy was the lunatics' ball (Figure 7), a monthly (sometimes weekly) event in most asylums, and an event frequently used to display the asylum's achievements to outsiders:

On the occasion of our visit there were about 200 patients present . . . in a raised orchestra, five musicians, three of whom were lunatics, soon struck up a merry polka, and immediately the room was alive with dancers. . . . Had the men been differently dressed, it would have been impossible to have guessed that we were in the midst of a company of lunatics, the mere sweepings of the parish workhouses; but the prison uniform of sad coloured grey appeared like a jarring note amid the general harmony of the scene. ... At nine precisely, although in the midst of a dance, a shrill note is blown and the entire assembly like so many Cinderellas, breaks up at once and the company hurry off to their dormitories. ${ }^{112}$

Madness domesticated (in my second sense) was madness tamed, and more effectively than the eighteenth century could ever have imagined.

pp. 65-66; Illustrated Times, 29 December 1859, quoted in Elaine Showalter, 'Victorian women and insanity', Chapter 12 in Andrew Scull (editor), Madhouses, mad doctors, and madmen, London, Athlone Press, 1981, p. 314; Dickens and Wills, op. cit., note 70 above.

${ }^{109}$ Showalter, op. cit., note 108 above.

${ }^{110}$ As Wynter (op. cit., note 90 above, p. 113) put it, "The decorous and regulated intercourse of the sexes is in itself a valuable lesson in self control."

11 Commissioners in Lunacy Annual Report, 1861, vol. 25, p. 131.

112 'Lunatic asylums', Quart. Rev., 1857, 101: 375-376. 